\title{
TANGGUNG JAWAB PT ASURANSI ASTRA BUANA DALAM ASURANSI MOBIL*
}

\author{
Oleh : \\ Ni Putu Mas Della Krista Winanda** \\ Anak Agung Ngurah Wirasila*** \\ Program Kekhususan Hukum Bisnis \\ Fakultas Hukum Universitas Udayana
}

\begin{abstract}
Abstrak
Karya tulis ini membahas mengenai Tanggung jawaban PT Asuransi Astra Buana dalam Asuransi Mobil. Tujuannya untuk mengetahui tanggung jawab PT Asuransi Astra Buana terhadap mobil yang mengalami kerusakan dan memahami pengaturan proses pembayaran klaim asuransi di PT Asuransi Astra Buana. Dilihat dari jenis penelitian normatif yang diteliti dalam perundang-undangan dan norma. Hasil dari penelitian ini yaitu PT Asuransi Astra Buana harus tanggung jawab kepada pihak tertanggung yang telah mengikuti asuransi mobil disebabkan sudah terikat dalam perjanjian yaitu dalam Pasal 1 ayat (1) Undang-Undang Nomor 40 Tahun 2014 tentang Perasuransian, PT Asuransi Astra Buana wajib memberikan tanggung jawab kepada tertanggung apabila dalam pelaksanaan ganti rugi penanggung akan memperhitungkan dengan premi yang masih terhutang untuk masa asuransi yang masih berjalan atas kendaraan tersebut, tertanggung wajib memberikan kesempatan kepada penaggung untuk memeriksa kerusakan sebelum dilakukan perbaikan atau penggantian atas kendaraan, tertanggung wajib memenuhi ketentuan-ketentuan yang sudah sesuai dengan prosedur melalui tahap-tahap yang harus dilakukan pada saat pengisian formulir harus benar dan jujur karena jika melakukan kesalahan sedikit saja maka pengajuan klaim kemungkinan besar akan dibatalkan. Kesimpulan dari penelitian ini adalah PT Asuransi Astra Buana wajib memberikan pengganti rugian dalam polis.
\end{abstract}

Kata Kunci: Pertanggungjawaban, Penanggung, Asuransi

\begin{abstract}
Abstrack
This paper discusses the Responsibility of PT Asuransi Astra Buana in Car Insurance. The goal is to find out the responsibility of PT Auransi Astra Buana for damaged car and understand the arrangement for the payment of insurance claims at PT Asuransi Astra Buana. Seen from the type of normative research examined in legislation and norms. The results of this study, namely PT Asuransi Astra Buana must be responsible to the insured party who has participated in disesbablan car insurance already bound to the agreement, namely in Article 1 paragtaph (1) about The Act

\footnotetext{
* Karya ilmiah ini merupakan ringkasan di luar skripsi.

** Ni Putu Mas Della Krista Winanda adalah mahasiswa Fakultas Hukum Universitas Udayana, korespondensi : dellakrista97@icloud.com

*** Anak Agung Ngurah Wirasila adalah dosen Fakultas Hukum Universitas Udayana.
} 
Numb. 40,2014 concerning about Insurance, PT Asuransi Buana must be responsible to the insured party if in the implementation of compensation the insurer will take into account the premiums that are still owed for the insurance period that are still running on the vehicle, the insured must provide an opportunity for the insurer to inspect the damage before repairs or replacements for the vehicle, the insured must fulfill the provisions of the provisions that are in accordance with the procedure through the stages that must be carried out at the time of filling out the form must be correct and honest because if you make a faw mistakes then the submission of claims is likely to be canceled. Replacement loss in the policy.

Keywords: Responsibility, Penanggung, Insurance

\section{PENDAHULUAN}

\subsection{Latar Belakang}

Transportasi merupakan sarana yang sangat penting bagi kehidupan masyarakat. Sejalan dengan hal tersebut, transportasi juga mengalami perkembangan yang sangat pesat sesuai dengan kemajuan masyarakatnya. Dengan transportasi masyarakat menjadi lebih mudah dan cepat menuju tempat yang diinginkan. Transportasi juga sangat membantu perusahaan dalam hal melakukan pengiriman barang kepada tertanggungnya. Pihak perusahaan juga mewajibkan agar barang tersebut sampai pada tujuan yang sudah ditentukan.

Kemajuan bidang transportasi membawa pengaruh besar di masyarakat dan semakin kedepan memacu perusahan untuk menghasilkan produk yang semakin canggih. Suatu perusahaan yang menjual kendaraan roda empat yaitu mobil khususnya terdapat perusahan yang sudah diunggulkan, disebabkan pelayanannya sangat baik. Hal ini sangat menguntungkan bagi pihak perusahaan sehingga masyarakat banyak yang berdatangan dan menjadi salah satu pilihan masyarakat untuk membeli kendaraan di perusahaan PT Auto 2000. Tertanggung langsung melakukan survei yaitu dengan datang ke lokasi keberadaan perusahaan sehingga dapat melakukan 
pemesanan barang secara langsung dan melakukan negosiasi kepada pihak petugas untuk melakukan pengisian formulir sesuai dengan yang sudah ditentukan oleh perusahaan yang berisikan identitas dan melakukan sebuah pembayaran apakah yang di bayar melalui cash atau kredit.

Setelah proses pengisian formulir selesai maka ditawarkan pengajuan asuransi yang bekerja sama dengan PT Asuransi Astra Buana untuk keamanan kendaraan. Jika dahulu tertanggung hanya mengenal Garansi sebagai keamanan mobil tetapi sekarang diadakannya yang namanya Asuransi, sebab tidak di ketahui apabila hal yang tidak diinginkan terjadi dalam berkendara seperti kecelakaan itu bisa datang kepada siapa saja dan dimana saja, adanya asuransi memudahkan tertanggung untuk lebih tenang dalam mengadapi masalah kendaraan.

Asuransi sangatlah penting untuk dimiliki dalam kendaraan roda empat atau kendaraan lainnya yang dapat dibilang memiliki kendaraan yang mewah, setiap perusahaan yang menjual kendaraan baik yang mewah atau yang tidak akan dianjurkan untuk membuka asuransi. Tetapi terdapat banyak permasalahan yang terjadi saat ini tentang klim asuransi yang sangat sulit agar kendaran yang mengalami kerusakan tersebut cepat untuk ditangani, sering sekali hal ini membuat binggung para tertanggung untuk memenuhi syaratsyarat yang harus ditaati dan banyak tertanggung tidak paham dengan ketentuan apa saja yang harus di lengkapi serta tidak semua perusahaan yang mau menerima biasanya hanya di perusahaan tempat membuat asuransi itu saja yang menerima, tempat lain ada juga yang tidak mau menerima pengajuan asuransi padahal dalam satu perusahaan yang sama tapi hanya tempatnya saja yang berbeda. 
Dikarenakan penanggung tidak menginformasikan secara lengkap hanya lebih menjelaskan pada keunggulan dari Asuransi saja.

Hal ini dibutuhkannya bentuk tanggung jawaban terhadap tertanggung yang telah mengikuti asuransi. Yang sudah terikat dalam perjanjian sesuai dengan Pasal 1 ayat (1) Nomor 40 Tahun 2014 tentang Perasuransian. Namun apabila pihak perusahaan tidak mau tanggung jawab sesuai dengan Pasal 19 ayat (1) UU Nomor 8 Tahun 1999 tentang Perlindungan Tertanggung (UUPK) yang menyatakan pelaku usaha bertanggungjawab memberikan ganti rugi atas kerusakan, pencemaran, dan atau kerugian kepada tertanggung akibat barang dan atau jasa yang dihasilkan atau diperdagangkan tidak sesuai.

\subsection{Rumusan Masalah}

Berdasarkan uraian latar belakang di atas, maka dalam tulisan ini akan membahas dua permasalahan yaitu :

1. Bagaimana tanggung jawab PT Asuransi Astra Buana terhadap mobil yang mengalami kerusakan?

2. Bagaimana pengaturan proses pembayaran klaim Asuransi Mobil di PT Asuransi Astra Buana?

\subsection{Tujuan Penulisan}

Tujuannya untuk mengetahui tanggung jawab PT Asuransi Astra Buana terhadap mobil yang mengalami kerusakan dan pengaturan proses pembayaran klaim Asuransi Mobil di PT Asuransi Astra Buana.

\section{ISI MAKALAH \\ 2.1 Metode Penelitian}


Penelitian ini menggunakan metode penelitian normatif, metode ini berdasarkan pada peraturan perundang-undangan serta literatur yang bersangkutan dengan permasalahan yang terjadi serta menggunakan metode penelitian yuridis normatif yang terdiri dari penelitian asas-asas hukum. ${ }^{1}$

\subsection{Hasil dan Analisis}

\subsubsection{Tanggung jawab PT Asuransi Astra Buana terhadap mobil yang mengalami kerusakan.}

Asuransi ditawarkan bertujuan agar kendaraan tersebut aman dan dapat dipertanggungjawabkan oleh perusahaan apabila mengalami kerusakan dan lain-lain. Jika tertanggung tidak mengikuti asuransi maka kerusakan yang terjadi bukan tanggungjawab dari pihak perusahaan, dikarenakan tidak adanya ikatan pada pihak perusahaan. Apabila pihak tertanggung sudah mengikuti asuransi dari perusahaan tempat membuat asuransi tersebut dan tidak ingin melakukan perbaikan kendaraan yang mengalami kerusakan serta tidak mau melakukan perbaikan kendaraan di perusahaan yang sudah menjadi kerjasama dalam pihak perusahaan maka tertanggung tidak dapat diterima dalam mengajukan klaim asuransi mobil karena tidak ada ikatan kerjasama dalam perusahaan itu.

Adapuun pihak perusahaan yang masi ingin membantu untuk membackup kerusakan yang terjadi tapi tidak semua perusahaan, disisi lain hanya mau membantu dalam mengatasi kerusakan yang dialami dalam hal pembiayaan atau pertanggungjawaban seluruhnya h. 12

${ }^{1}$ H. Zainuddin Ali, 2017, Metode Penelitian Hukum, Sinar Grafika, Jakarta, 
menjadi pihak tanggungjawab tertanggung karena tidak ada ikatan asuransi. Menjalankan kegiatan usha yang diatur dalam UUPK yang menjelaskan bahwa penanggung harus bertanggung jawab dalam kesalahan yang terjadi baik sengaja maupun tidak sengaja dengan demikian pihak perusahaan tersebut harus memberikan bentuk kompentensi, penggantian barang apa barang yang diterima tidak sesuai dengan mengenai yang diterima tidak sesuai dengan apa yang dinginkan atau terjadi kerusakan.

Berdasarkan pada substansi dalam Pasal 19 ayat (1) UUPK mengenai pertanggungjawaban penanggung sebagai pelaku usaha dapat diketahui meliputi:

1. Tanggungjawab ganti rugi atas kerusakan;

2. Tanggungjawab kerugian yang terjadi; dan

3. Tanggungjawab ganti rugi yang telah membuat tertanggung menjadi rugi.

Prinsip tentang tanggungjawab merupakan hal yang sangat penting di hukum perlindungan tertanggung.Perlindungan tertanggung mempermudah untuk mengetahui pihak mana yang harus bertanggungjawab terhadap kerugian yang diderita oleh tertanggung. ${ }^{2}$ Perusahan yang menjual kendaraan roda empat, dalam pihak perusahaan ini akan mengeluarkan bentuk pertanggungjawabnya apabila pihak tertanggung sudah menenuhi ketentuan-ketentuan berupa pengecekan terhadap kelengkapan dalam mengajukan pengklaim asuransi mobil yang mengalami kerusakan yang dilakukan oleh nasabah itu sendiri yang harus lengkap.Pihak tertanggung dapat menggunakan asuransinya dalam

2 Aulia Muthiah,2016, Hukum Perlindungan Konsumen Dimensi Hukum Positif dan Ekonomi Syariah, Yogyakarta, Pustaka Baru, h. 107 
kerusakan kendaraannya, disamping itu memberikan keuntungan bagi kedua belah pihak. ${ }^{3}$ Namun apabila pihak tertanggung tidak mengikuti asuransi maka kerusakan yangterjadi bukan tanggung jawab penanggung tetapi sepenuhnya tanggungjawab dari tertanggung.

Asuransi adalah lembaga ekonomi yang bertujuan mengurangi risiko dengan jalan mengombinasikan dalam suatu pengelolaan sejumlah objek yang cukup besar jumlahnya, sehingga kerugian tersebut secara menyeluruh dapat digunakan dalam waktu-waktu tertentu yang seharusnya digunakan. ${ }^{4}$

\subsubsection{Pengaturan Proses Pembayaran klaim Asuransi Mobil di PT Asuransi Astra Buana.}

Permasalahan yang terjadi antara penanggung dengan tertanggung dapat diselesaikan melalui penyelesaian sengketa abritase. Abritrase merupakan cara penyelesaian suatu sengketa perdata diluar peradilan umum didasarkan pada perjanjian arbitrase yang dibuat secara tertulis oleh para pihak yang bersengketa. ${ }^{5}$ Tertanggung yang dirugikan memerlukan perlindungan untuk mendapatkan pertanggungjawaban atas dasar kesalahan pelaku usaha, namun dalam hal ini hukum juga harus mengatur keadilam antara tertanggung dengan penanggung. ${ }^{6} \mathrm{Hal}$ ini disebabkan karena banyak pelaku usaha untuk mendapatkan keuntungan semata tanpa mau bertanggungjawab atas produk dari pihak perusahaan itu

\footnotetext{
${ }^{3}$ Rudyanti Dorotea Tobing, 2015, Hukum Konsumen Dan Masyarakat ( Sebuah Bunga Rampai), Yogyakarta, h.41

4 Mulhadi, 2017, Dasar-Dasar Hukum Asuransi, Kota Depok, PT Raja Grafindo Persada, h.4

5 Dewa Nyoman Rai Asmara Putra, ddk, 2017, Buku Ajar Hukum Penyelesaian Sengketa Bisnis, Tabanan, Bali, Pustaka Ekspresi, h.11

${ }^{6}$ Ibid., h. 13
} 
sendiri. 7 Tertanggung berhak untuk meminta segala sesuatu yang sudah diperjanjikan apabila telah mengikuti asuransi mobil di perusahaan tersebut.

Asuransi termasuk jasa yang bisa dinimati oleh tertanggung dengan terlebih dahulu menandatangi polis sebagai bentuk persetujuan keikut sertaan dengan memenuhi kewajiban membayar premi setiap bulan atau tahunan. Permasalahan asuransi sering membuat kondisi tertanggung diposisi yang lemah. Hubungan antara Perusahaan Asuransi dan nasabahnya diatur dalam perjanjian yang mengikat dan disepakati oleh kedua belah pihak. ${ }^{8}$

Pengaturan asuransi dalam KUHD mengutamakan segi keperdataan yang didasarkan pada perjanjian antara tertanggung dan penanggung. Perjanjian tersebut menimbulkan kewajiban dan hak tertanggung serta penanggung secara timbale balik. Sebagai perjanjian khusus, asuransi dibuat secara tertulis dalam bentuk akta yang disebut polis asuransi. Terdapat peraturan asuransi dalam KUHD meliputi yaitu: asas asuransi, perjanjian asuransi, unsurunsure asuransi, syarat-syarat (klausula asuransi, jenis-jenis asuransi. 9

Dalam melakukan klaim asuransi mobil, jika pihak tertanggung dengan benar serta melengkapi semua berkas yang sudah ditentukan, klaim asuransi sangat mudah untuk diproses. Terlebih dahulu langkah pertama yang dilakukan untuk melakukan klaim asuransi mobil adalah ketika mobil mengalami kecelakaan atau kerusakan langsung untuk mengambil foto mobil yang lecet atau

7 Ibid., h.107

8 Cerlina Tri Siwi Kristiyani, 2018, Hukum Perlindungan Konsumen, Jakarta, Sinar Grafika, h. 158

9 Abdulkar Muhammad, 2015, Hukum Asuransi Indonesia, Bandung, PT Citra Aditya Bakti, h.18 
rusak parah saat jadi kecelakan. Sesudah itu terdapat prosedur umum dalam setiap pengajuan klaim asuransi yaitu:

1. Dengan menghubungi pihak asuransi

2. Mempersiapkan dokumen-dokumen penting dalam pengajuan klaim seperti yang paling penting surat polis, KTP, SIM C dan juga surat keterangan kepolisian jika kendaraan rusak akibat terjadinya kecelakaan.

3. Setelah semua persyaratan sudah dipenuhi dan sesuai dengan ketentuan dari pihak asuransi maka mobil segera untuk dibawa ke bengkel yang sudah berkerjasama dengan asuransi tersebut untuk dilakukannya pengecekan. Tidak diperbolehkan untuk memperbaiki mobil dibekel yang bukan rekan kerjasama dari asuransi tersebut karena bisa kemungkinan klaim akan ditolak karena tidak memiliki ikatan kerja satu sama lain.

4. Tahap terakhir dalam mengajukan tertanggung diharapkan untuk mengisikan formulir sejelas-jelasnya dan selengkaplengkapnya mengenai kecelakaan yang terjadi kapan dan dimana terjadinya kecelakaan tersebut, karena apabila ada kesalahan sedikit saja mengenai pengisian formulir maka besar kemungkinan klaim akan ditolak. Maka isilaj sejujurjujurnya untuk mempermudah klaim asuransi cepat untuk diproses dan kendaraan cepat untuk ditangani.

Pada saat terjadinya kerugian atau kerusakan yang dialami oleh pihak tertanggung sangat penting bagi pemilik kendaraan untuk memahami ketentuan yang berlaku dalam polis asuransi kendaraan tersebut. Asuransi merupakan bentuk perlindungan yang financial yang diberikan oleh suatu perusahaan asuransi dimana orang yang 
mengajukan asuransi bertindak sebagai tertanggung dan perusahaan asuranasi sebagai penanggung. Sehingga perlindungannya akan berjalan sesuai prosedur dengan terlebih dahulu harus membayar premi yang dibayarkan disetiap bulannya atau tahunan. Pada saat terjadinya kerugian atau kerusakan yang dialami oleh pihak tertanggung sangat penting bagi pemilik kendaraan untuk memahami ketentuan yang berlaku dalam polis asuransi kendaraan tersebut. Terdapat beberapa hal yang harus di perhatikan dan dihindari dalam asuransi kenndaaran agar mendapatkan pertanggung jawaban dari penanggung, disebabkan adanya beberapa hal yang bisa membuat asuransi angus dan tidak dapat di tanggung jawabkan disebabkan

1. Masa berlaku polis tersebut berakhir

2. Masa berlaku SIM berakhir

3. Sengaja menghilangkan kedaraan.

Terdapat kerugian yang dialami oleh pihak tertanggung akibat mengalami kerusakan, pihak tertanggung meminta pertanggungjwabanan terhadap penanggung akibat barang yang mengalami kerusakan sesuai dengan prosedur yang sudah ditetapkan. Apabila pihak tertanggung sudah mengikuti proses pembayaran premi secara lancar maka semua resiko yang terjadi pada mobil mulai dari kerusakan ringan, kerusakan berat hingga kehilangan pihak penanggung akan menanggung semua resiko yang terjadi. Kerusakan yang terjadi sebaiknya tertanggung untuk lebih berhati-hati dan perusahaan hendaknya harus beritikad baik dalam menjalankan kegiatan usahanya agar tidak melakukan perbuatan yang dapat merugikan tertanggung, karena perlindungan bagi 
tertanggung sudah diterapkan di dalam UUPK dan sebelumnya diadakanya perjanjian bagi kedua belah pihak.

Adapuun syarat sahnya berlakunya perjanjian berdasarkan Pasal 1320 KUHPerdata yaitu:

1. Adanya kesepakatan diantara mereka yang membuat perjanjian;

2. Kecapakan masing-masing pihak dalam membuat perjanjian;

3. Adanya persoalan tertentu; dan

4. Sebab yang halal

\section{PENUTUP}

\subsection{Kesimpulan}

Tanggung jawaban penanggung terhadap tertanggung yang sudah mengikuti asuransi kendaraan roda empat, dalam hal ini pihak perusahaan akan mengeluarkan tanggung jawab apabila pihak tertanggung sudah menenuhi ketentuan-ketentuan berupa pengecekan terhadap kelengkapan dalam pengajuan klaim asuransi mobil yang mengalami kerusakan secara lengkap dan penanggung akan memberikan tanggung jawabnya.

Pengaturan proses pembayaran klaim asuransi mobil, pihak tertanggung wajib untuk mengikuti prosedur dan syarat-syarat yang sudah sesuai dengan perusahaan tersebut

\subsection{Saran}

Penanggung sebaiknya lebih jelas untuk memberikan informasi dan menjelaskan mengenai pengajukan klaim asuransi mobil sehingga para tertanggung tidak kebinggungan. Tertanggung sebaiknya mendengarkan dengan baik ketentuan - ketentuan yang 
harus diikuti sesuai dengan prosedur pihak perusahaan tersebut dan tidak perlu khawatir apabila kendaraan tersebut sudah terdaftar asuransi.

\section{DAFTAR PUSTAKA}

\section{BUKU}

Muthiah, Aulia, 2016, Hukum Perlindungan Tertanggung Dimensi Hukum Positif dan Ekonomi Syariah, Yogyakarta.

Ali, H. Zainuddin 2017, Metode Penelitian Hukum, Sinar Grafika, Jakarta.

Cerlina Tri Siwi Kristiyani, 2018, Hukum Perlindungan Tertanggung, Jakarta, Sinar Grafika.

Rai Asmara Putra, Dewa Nyoman, dkk, 2017, Buku Ajar Hukum Penyelesaian Sengketa Bisnis, Tabanan, Bali, Pustaka Ekspresi.

Mulhadi, 2017, Dasar-Dasar Hukum Asuransi, Kota Depok, PT RajaGrafindo Persada.

Tobing Dorotea Rudyanti, 2015, Hukum, Tertanggung Dan Masyarakat ( Sebuah Bunga Rampai), Yogyakarta.

Ganie Junaedy, 2013, Hukum Asuransi Indonesia, Sinar Grafika, Jakarta.

\section{JURNAL ILMIAH}

Windari Artha Ratna, 2015, Pertanggungjawaban Mutlak ( Strict Liability ) Dalam Hukum Perlindungan Tertanggung, Jurnal Fakultas Hukum, Volume I, Nomor 1, Pebruari 2015, Buleleng, Bali.

\section{PERATURAN PERUNDANG_UNDANGAN}

Kitab Undang-Undang Hukum Dagang. 
Undang-Undang Nomor 40 Tahun2014 tentang Perasuransian

Undang-Undang Nomor 8 Tahun 1999 tentang Perlindungan Tertanggung. 